Ткачук М. М., А.т.н., професор, Ткачук Р. М., к.т.н., Білецький А. А., к.т.н., доцент (Національний університет водного господарства та природокористування, м. Рівне)

\title{
ВОДОРЕГУЛЮВАННЯ ДРЕНАЖНО-МОДУЛЬНИМИ СИСТЕМАМИ НА ОСУШУВАНИХ ЗЕМЛЯХ
}

У статті розглянуто водорегулювання дренажно-модульними системи з різнорівневим підключенням регулюючих дрен на осушуваних землях, приведено схеми їх конструктивних параметрів. Наведено результати досліджень та методи розрахунку параметрів цих систем.

Ключові слова: водорегулювання, удосконалення водорегулювання, дренажно-модульні системи, різнорівневі регулюючі дрени, осушувані землі.

Вступ. В сучасних умовах регулювання водного режиму ґрунтів на перезволожених землях гумідної зони здійснюється шляхом застосування традиційного закритого дренажу на осушувальних системах та шлюзів-регуляторів на відкритих каналах і регуляторів на колекторах. Однак ці системи недостатньо ефективні при попереджувальному, а тим більше при зволожувальному шлюзуванні. Вони також капіталомісткі при будівництві та експлуатації $[1 ; 2 ; 3]$.

Результати досліджень. Нами розроблено та досліджено в лабораторних і виробничих умовах конструкції дренажно-модульних систем (ДМС) з різнорівневим підключенням регулюючих дрен (рис. 1), що відповідають сучасним інноваційним вимогам і мають переваги над традиційними осушувальними системами (конструкція досліджена і захищена патентами [4].

Принциповою особливістю конструкції дренажно-модульної системи з різнорівневим підключенням регулюючих дрен $\epsilon$ те, що суміжні дрени гідравлічно пов'язані між собою і здатні виконувати такі важливі гідравлічні функції:

1) інтенсивно понижувати рівні ґрунтових вод (РГВ) до норми осушення в критичні періоди роботи дренажу (літні зливові дощі, період повеней); 


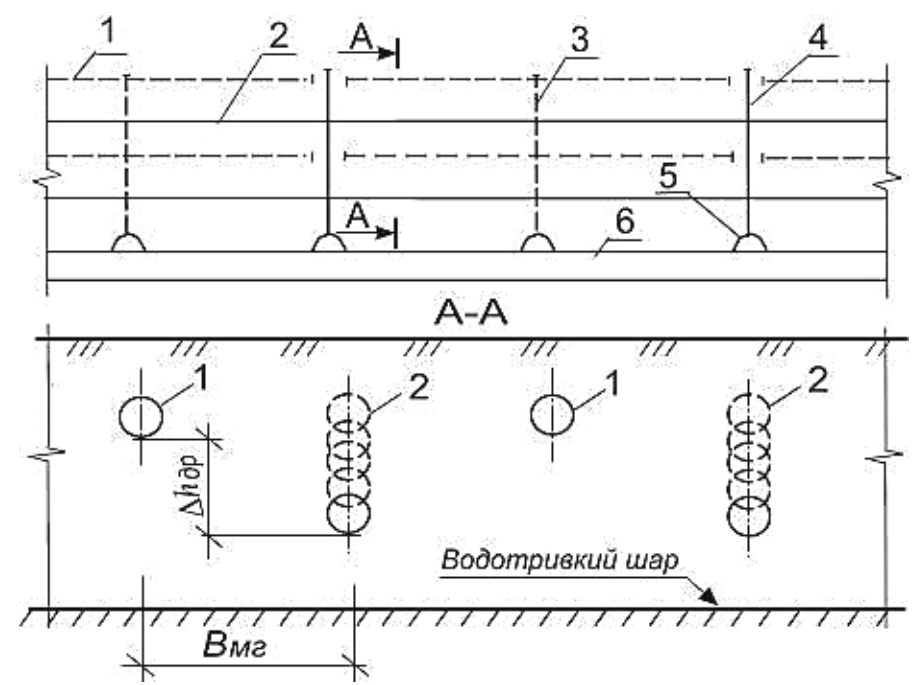

Рис. 1. Загальний вигляд конструкції дренажно-модульної системи 3 різнорівневим підключенням регулюючих дрен: 1 - дрена мілкого закладання; 2 - дрена мілко-глибокого закладання; 3 - колектор мілкого закладання; 4 - колектор глибокого закладання; 5 - гирло; 6 - канал

2) акумулювати вологу в межах глибин мілкого і мілкоглибокого закладання дрен за рахунок особливого розташування регулюючих дрен, (за принципом попереджувального шлюзування) та шляхом саморегулювання РГВ упродовж вегетаційного періоду, не допускаючи при цьому надлишку або дефіциту вологи у кореневмісному шарі ґрунту.

Разом з цим, ефективне регулювання рівнів ґрунтових вод (водного режиму ґрунтів) дренажно-модульною системою залежить від ряду факторів, серед яких найбільш суттєве значення мають відстань між дренами, глибина закладання дрен, коефіцієнт фільтрації ґрунтів, глибина залягання ґрунтових вод, погодні фактори тощо.

Визначення відстані між дренами є надто складним завданням, оскільки дуже тяжко врахувати всі ці фактори і їх взаємозв'язок, більше того деякі з них міняються як в часі, так і в просторі. Саме цим і пояснюється велика кількість методів визначення відстаней між дренами в літературних джерелах [5; 6; 7; 8; 9].

Що стосується розрахунку відстаней між дренами дренажномодульних систем з різнорівневим підключенням регулюючих дрен, то за результатами теоретичних та експериментальних (лабораторних та польових) досліджень нами удосконалено загальноприйняті методи та математичні моделі, що описують рух води в ґрунті і на основі цих досліджень запропоновано метод розрахунку відстаней (1) 
між досконалими дренами дренажно-модульної системи при ґрунтовому живленні

$$
B_{\text {м⿱ }}=\sqrt{\frac{k_{\phi}\left(h_{0}^{2}-h_{2}^{2}\right)}{q_{2}}\left(1+\frac{m_{2}^{2}}{h_{0}^{2}}\right)}+\sqrt{\frac{k_{\phi}\left(h_{0}^{2}-h_{1}^{2}\right)}{q_{1}}\left(1+\frac{m_{1}^{2}}{h_{0}^{2}}\right)}
$$

де $B_{\text {мг }}$ - відстань між дренами мілкого і мілко-глибокого закладання, м; $k_{\phi}$ - коефіцієнт фільтрації ґрунту, м/добу; $h_{0}$ - глибина від рівня ґрунтової води до водотривкого шару, м; $h_{1}, h_{2}$ - напір відповідно на дрену мілкого та мілко-глибокого закладання; $m_{1}$ - потужність водоносного шару під дреною мілкого закладання, м; $m_{2}$ - потужність водоносного шару ґрунту під дреною мілко-глибокого закладання, м; $q_{1}$ - інтенсивність притоку води до дрени мілкого закладання, м/добу; $q_{2}$ - інтенсивність притоку води до дрени мілкоглибокого закладання, м/добу.

Рівняння (1) враховує просторове розташування дрен дренажно-модульної системи, що має ряд відмінностей від традиційного дренажу, а саме: лише гирлова частина дрени мілко-глибокого закладання може розташовуватися на водотривкому шарі і майже вся іï довжина та дрена мілкого закладання знаходяться над водотривким шаром (схему для розрахунку відстаней між дренами ДМС з різнорівневим підключенням регулюючих дрен наведено на рис. 2).

Для уточнення запропонованого методу розрахунку відстані між дренами мілкого та мілко-глибокого закладання ДМС, визначено розрахунковий напір на дрену мілко-глибокого закладання.

Оскільки ключовими в рівнянні (1) є напори і витрати води 3 дрен, то для обґрунтування можливості застосування залежності (1)

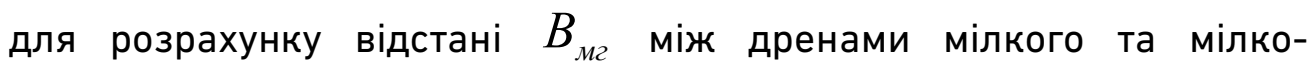
глибокого закладання, виконаємо дослідження напорів і витрат води з дрен, що є складовими розрахунковими параметрами рівняння (1). Розглянемо і проаналізуємо схему (рис. 3). 


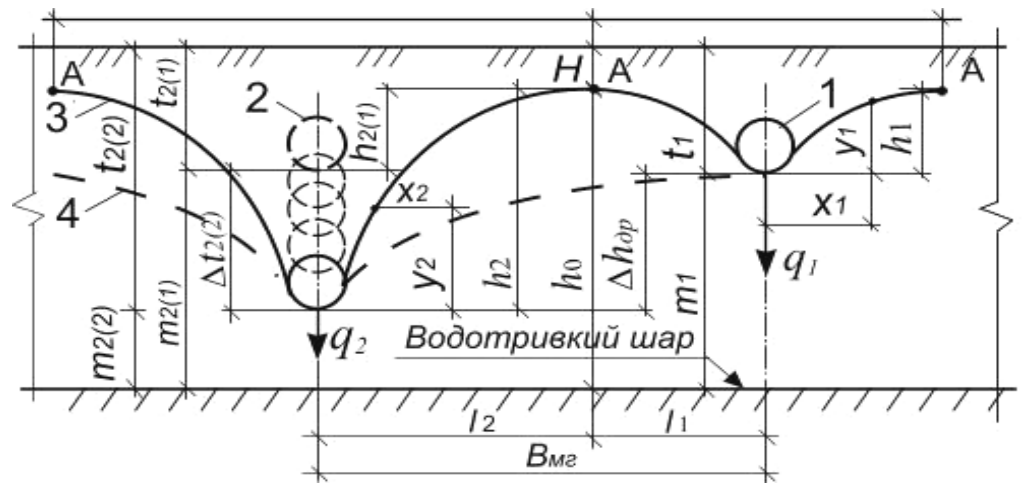

Рис. 2. Схема до розрахунку відстані Вмг між дренами мілкого і мілко-глибокого закладання: 1 - дрена мілкого закладання; 2 - дрена мілко-глибокого закладання; 3 - режим формування дренажного стоку в період повеневого циклу (інтенсивного пониження РГВ до норми осушення H); 4 - режим регулювання РГВ упродовж вегетаційного періоду (в межах дрен мілкого і мілко-глибокого закладання); $l_{1}, l_{2}$ - відповідно, відстань від водорозділу (точка А) до дрен мілкого і мілко-глибокого закладання;

$B_{r}, B_{\text {м }}$ - відповідно, відстані впливу дрен мілкого і мілко-глибокого закладання (з двох боків)

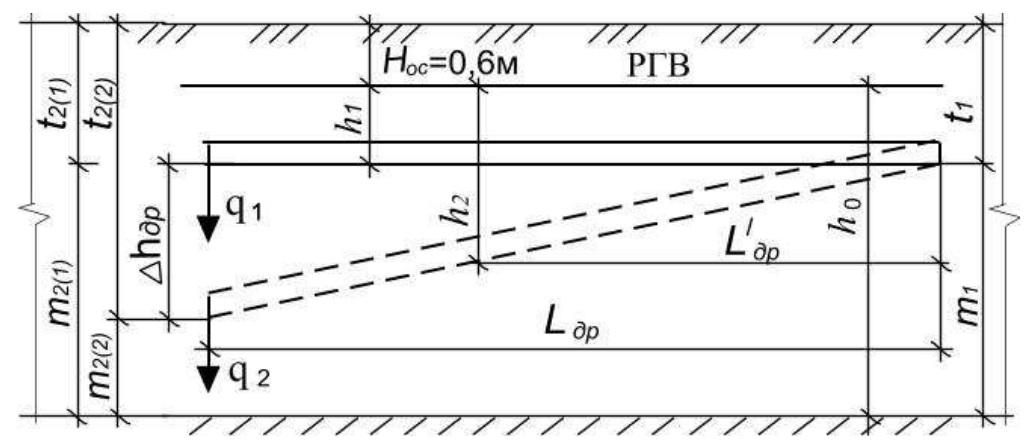

Рис. 3. Схема для дослідження напору і витрат води з дрен, що $€$ складовими параметрами при розрахунку відстані між дренами ДМС

Згідно із розрахунковою схемою (рис. 3), при сталому РГВ, напір $h_{1}$ на дрену мілкого закладання вздовж ії довжини не змінюється i дорівнює

$$
h_{1}=h_{0}-m_{1, \mathrm{M}}
$$

Напір $h_{2}$ на дрену мілко-глибокого закладання при тих самих умовах буде змінюватися по довжині дрени, при цьому найменше його значення буде дорівнювати $h_{1}$, а найбільше 


$$
h_{2}=h_{1}+\Delta h_{\partial p}, \mathrm{м}
$$

Виходячи з (2) і (3) та розрахункової схеми (рис. 3), напір на дрену мілко-глибокого закладання буде змінюватися в межах

$$
h_{1} \leq h_{2}<h_{1}+\Delta h_{\partial p}
$$

При зміні напорів на дрену мілко-глибокого закладання (внаслідок іï різнорівневого положення) буде змінюватися відстань до водотривкого шару $m_{2}$ і знаходитися в межах

$$
m_{1} \leq m_{2}<m_{1}+\Delta h_{\partial p} .
$$

Для будь-якого перетину дрени мілко-глибокого закладання (рис. 3) на відстані $L_{\partial p}^{\prime}$ від витоку, $m_{2}$ можна знайти за формулою

$$
m_{2}=m_{1}-\Delta h^{\prime}
$$

де $\Delta h^{\prime}$ - перевищення між витоком дрени мілко-глибокого закладання та частиною, яка знаходиться на відстані $L_{\partial p}^{\prime}$ від витоку (різниця напорів на дрені мілко-глибокого та мілкого закладання на відстані $\left.L_{\partial p}^{\prime}\right) . \Delta h^{\prime}$ можна визначити

$$
\Delta h^{\prime}=\frac{\Delta h_{\partial p}}{L_{\partial p}} L_{\partial p}^{\prime},
$$

де $\Delta h_{\partial p}$ - перепад між дренами мілкого та мілко-глибокого закладання в гирлі дрени; $L_{\partial p}$ - довжина дрени; $L_{\partial p}^{\prime}-$ відстань дрени від витоку до точки, на якій знаходитися напір $\Delta h^{\prime}{ }_{(} L_{\partial p}^{\prime}$ змінюється від 0 до $L_{\partial p}$ ).

Тоді відстань від водотривкого шару до дрени мілко-глибокого закладання $m_{2}$ в точці віддаленій від ії витоку на відстань $L_{\partial p}^{\prime}$, буде дорівнювати

$$
m_{2}=m_{1}-\Delta h^{\prime}=m_{1}-\frac{\Delta h_{\partial p}}{L_{\partial p}} L_{\partial p}^{\prime}
$$


Як зазначалось, напір на дрену мілко-глибокого закладання змінюється вздовж ії довжини (3), тоді врахувавши (7), можна знайти цей напір в точці, віддаленій від їі витоку на $L_{\partial p}^{\prime}$

$$
h_{2}=h_{1}-\frac{\Delta h_{\partial p}}{L_{\partial p}} L_{\partial p}^{\prime} .
$$

Для знаходження відстані між дренами за рівняннями (1) і (3), визначимо розрахункове значення напору на дрену мілко-глибокого закладання (чисельник лівої частини суми під коренем).

Очевидно, що це $є$ усереднене значення напору вздовж довжини дрени (рис. 4) можна отримати, побудувавши епюру напорів на дрену глибокого закладання вздовж ії довжини.

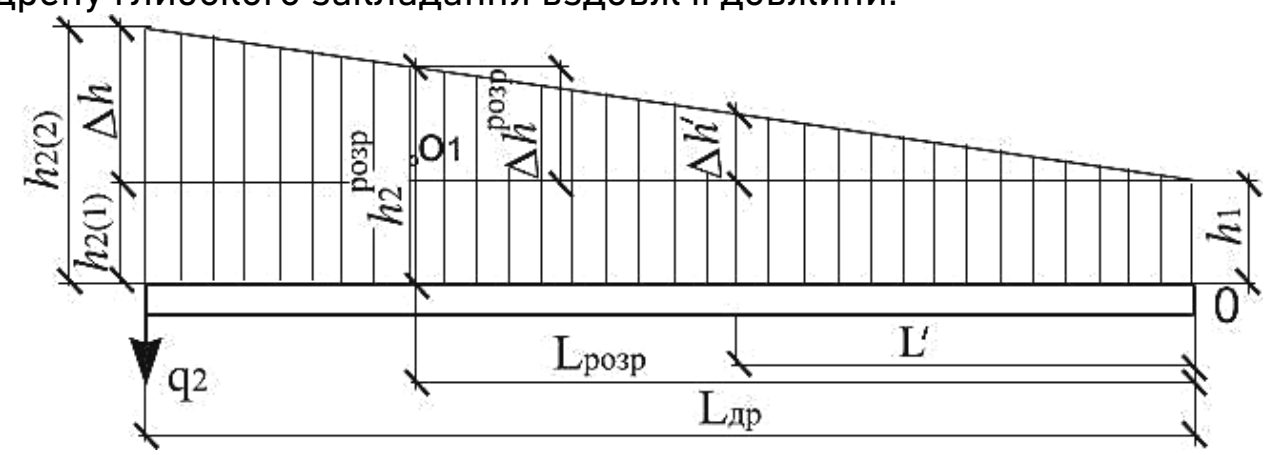

Рис. 4. Схема для визначення розрахункового напору на дрену мілко-глибокого закладання ДМС з різнорівневим підключенням регулюючих дрен

Усереднене значення напору $\Delta h_{\text {розр }}$ - це нормаль до осі дрени, яка лежить в межах епюри напорів та проходить через центр мас утвореної фігури. До того ж, поперечний переріз відносно осі дрени в точці $0_{1} \in$ розрахунковим для даної ДМС.

Відстань від витоку дрени (точка 0) до проекції центра мас буде визначатися

$$
L_{\text {розр }}=\frac{\sum F_{i} L_{i}}{\sum F_{i}}=\frac{\left(L_{\partial p} h_{1}\right) \frac{L_{\partial p}}{2}+\left(\frac{L_{\partial p} \Delta h}{2}\right) \frac{2 L_{\partial p}}{3}}{\left(L_{\partial p} h_{1}\right)+\left(\frac{L_{\partial p} \Delta h}{2}\right)}=L_{\partial p} \frac{3 h_{1}+2 \Delta h}{6 h_{1}+3 \Delta h},
$$

де $F_{i}-$ площі фігур, що утворюють епюру напорів (рис. 4); $L_{i}-$ відстань від точки 0 до центра мас фігур, що утворюють епюру напорів (рис. 4). 
Відповідно з (7) розрахунковий напір на відстані $L_{\text {розр }}$ від витоку дрени буде рівний

$$
h_{2}^{\text {розр }}=h_{1}+\frac{3 h_{1} \Delta h+2 \Delta h^{2}}{6 h_{1}+3 \Delta h}=h_{1}+\Delta h_{\text {розр }}
$$

де $\Delta h_{\text {розр }}$ - усереднена різниця напорів між дреною глибокого та мілкого закладання, яка виходячи з (11), буде рівна

$$
\Delta h_{\text {розр }}=\frac{3\left(h_{0}-m_{1}\right) \Delta h+2 \Delta h^{2}}{6\left(h_{0}-m_{1}\right)+3 \Delta h} .
$$

3 рис. 4 та формули (10) відстань від дрени глибокого закладання до водотривкого шару в точці, віддаленій від їі витоку на відстань $L_{\text {розр }}$ (розрахунковий переріз ДМС) буде дорівнювати

$$
m_{2}=m_{1}+\Delta h_{\text {розр }} \text {. }
$$

Відповідно до формули (12), якщо гирлова частина дрени мілкоглибокого закладання розташована на водотривкому шарі, то розрахунок відстані між дренами мілко-глибокого та мілкого закладання ДМС слід виконувати за скоригованою формулою

$$
B_{\text {ме }}=h_{0}\left[\sqrt{\frac{k}{q_{1}}\left(1+\frac{m_{1}^{2}}{h_{0}^{2}}\right)}+\sqrt{\frac{k}{q_{2}}\left(1+\frac{m_{2}^{2}+\Delta h_{\text {розр }}^{2}}{h_{0}^{2}}\right)}\right] \text {, }
$$

де $h_{0}$ - максимальний рівень ґрунтової води між дренами, м; $m_{1}-$ потужність водоносного шару під дреною мілкого закладання, м; $\Delta h_{\text {розр }}$ - перепад між глибинами дрен мілкого і глибокого закладання (розраховується за формулою 12); $q_{1}, q_{2}$ - інтенсивність притоку води до дрен, відповідно, до мілко-глибокого та мілкого закладання.

У формулі (14) усі величини відомі, крім $q_{1}, q_{2}$ і відстаней $B_{\mathcal{~}}$ між дренами мілко-глибокого і мілкого закладання.

Для дослідження гідрологічної дії регулюючої ДМС розглянемо схему (рис. 5). 


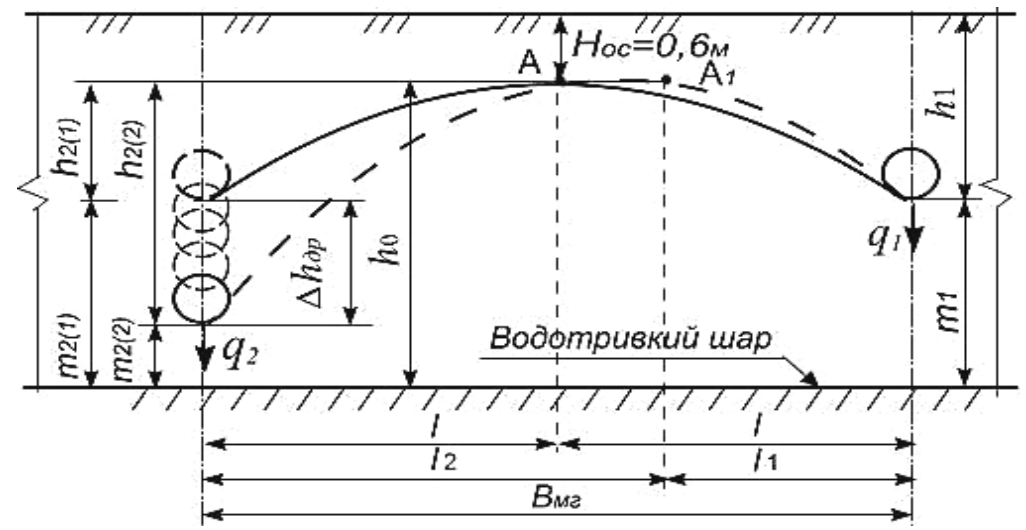

Рис. 5. Схема для дослідження зміни $q_{1}$ і $q_{2}$ внаслідок гідрологічної дії ДМС при зміні глибини закладання різнорівневої глибокої дрени від витоку до їі гирла: А - точка водорозділу між мілкими дренами; $A_{1}$ - точка водорозділу між дренами мілкого і мілко-глибокого закладання

Отже, відповідно до схеми (рис. 5) $\bar{q}$ можна виразити через

$$
\bar{q}=\frac{q_{1}+q_{2}}{2},
$$

де $\bar{q}$ - середня, за розрахунковий період, інтенсивність притоку води до мілко-глибокої та мілкої дрен, м/добу; $q_{1}$ - інтенсивність притоку води до мілко-глибокої дрени (при відстані між глибокими дренами $B_{r}$, рис. 5); $q_{2}$ - інтенсивність притоку води до дрени мілкого

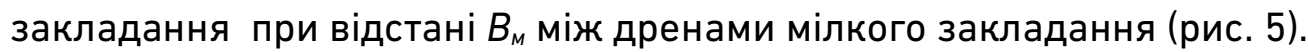

Використовуючи дослідження [10], також можна записати, що

$$
\begin{aligned}
& q_{1}=\alpha_{1} \bar{q} \\
& q_{2}=\alpha_{2} \bar{q} .
\end{aligned}
$$

де $\alpha_{1}, \alpha_{2}$ - коефіцієнти, що залежать від значень перепаду $\Delta h_{\partial p}$ і враховують перерозподіл стоку між глибокою та мілкою дренами.

Підставивши (17) і (18) у (16), отримаємо:

$$
\begin{gathered}
\bar{q}=\frac{\alpha_{1} \bar{q}+\alpha_{2} \bar{q}}{2}=\frac{\bar{q}\left(\alpha_{1}+\alpha_{2}\right)}{2} . \\
\alpha_{1}+\alpha_{2}=2 .
\end{gathered}
$$

Таким чином $\alpha_{2}$, можна виразити через $\alpha_{1}$

$$
\alpha_{1}=2-\alpha_{2}
$$


Оскільки значення коефіцієнтів $\alpha_{1}$ і $\alpha_{2}$ залежать від значень $\Delta h_{\partial p}$, то при $\Delta h_{\partial p}=0$ коефіцієнти $\alpha_{1}, \alpha_{2}$ будуть дорівнювати 1 (одиниці), а стік з дрен буде рівний між собою. При максимальному $\Delta h_{\partial p}=0,6$ м спостерігається максимальна різниця між коефіцієнтами $\alpha_{1}$ і $\alpha_{2}$, а разом з тим і функціональна залежність між цими величинами. Знаючи, що при $\Delta h_{\partial p}=0 \quad \alpha_{2}=1$ і $\alpha_{1}=1$, а при $\Delta h^{\prime}=0,6$ м (теоретично максимально можливий перепад, коли дрена мілкого закладання виключається з роботи), то при $m_{1}=1,4$ м, $h_{1}=H_{o c}=0,6 \quad$ м, $\alpha_{2}=2$ можна побудувати залежність $\alpha_{2}=f\left(\Delta h_{\partial p}\right)$ (рис. 6) і отримати формулу, що ії описує. Згідно з рис. 6 залежність $\alpha_{2}=f\left(\Delta h_{\partial p}\right)$ можна описати математично

$$
\alpha_{2}=1,6667 \cdot \Delta h_{\partial p}+1 \text {. }
$$

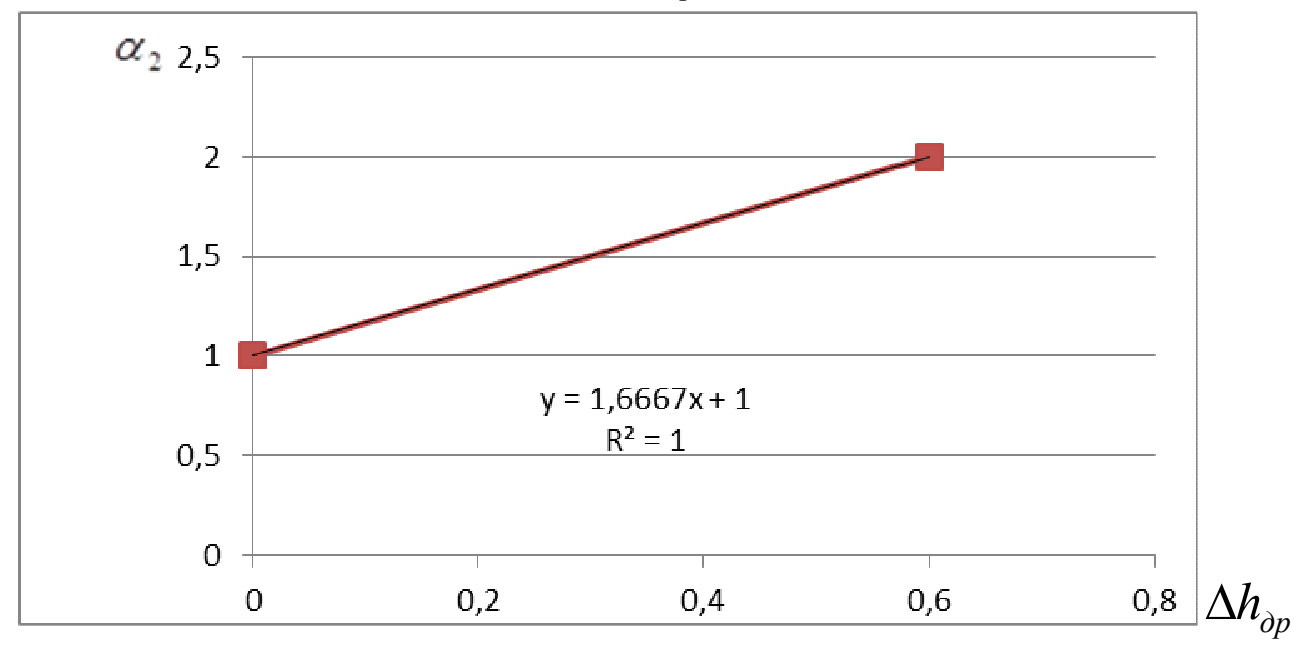

Рис. 6. Графік залежності $\alpha_{2}=f\left(\Delta h_{\partial p}\right)$

Отже, змінюючи положення дрени мілко-глибокого закладання відносно дрени мілкого закладання, збільшуючи перепад $\Delta h_{\partial p}$ між дренами (в напрямку водотривкого шару), можна визначити всі складові параметри формули (14).

Згідно з приведеними розрахунками можна побудувати графік (рис. 7) залежності $B_{\text {м⿰ }}=f\left(m_{2}\right)$ - відстані між дренами та відстані 
від дрени глибокого закладання до водотривкого шару.

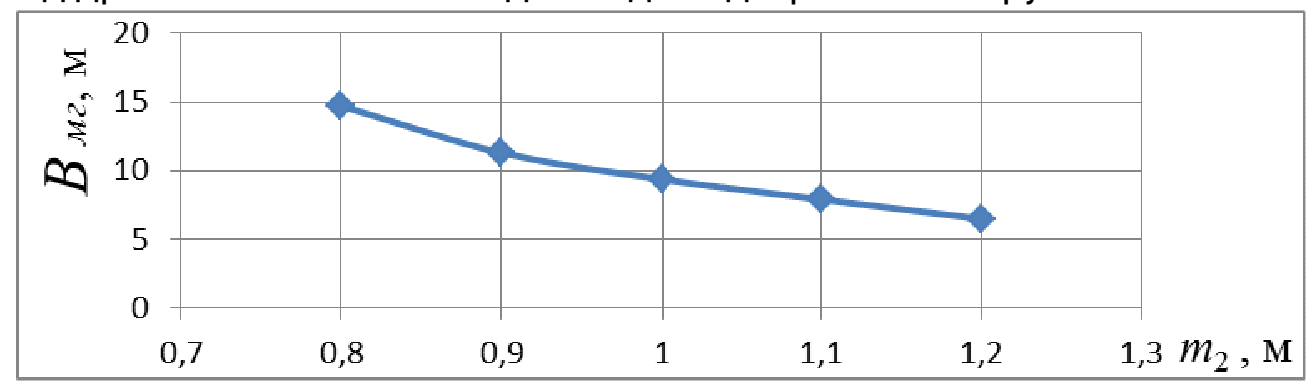

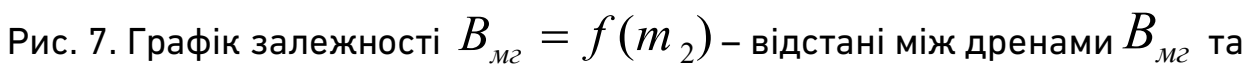

відстані від дрени глибокого закладання до водотривкого шару $m_{2}$

3 графіка (рис. 7) видно, що при збільшенні глибини дрени мілко-глибокого закладання, збільшується відстань між дренами. При цьому, зі зміною $\Delta h_{\partial p}$ від $\Delta h_{\partial p}=0$ у витоку з дрени, до $\Delta h \max =$ 0,6 м у гирловій частині, $q_{2}$ буде змінюватися від $q_{1} \min$ до $q_{2} \max$.

\section{Висновки}

1. За результатами теоретичних та експериментальних (лабораторних та польових) досліджень удосконалено математичну модель та основі загальноприйнятих методів, запропоновано метод розрахунку відстані між дренами мілкого і мілко-глибокого закладання залежно від напору та притоку води до них.

2. Встановлено, що стік води $q$ з дрени мілко-глибокого закладання, підключеної одночасно до мілкого та глибокого колекторів, змінюється по довжині глибокої дрени (від витоку до гирла), залежно від напору $h_{2}$, від 0,62 до 0,02 м/добу, що дозволяє забезпечувати сільськогосподарські культури ґрунтовою водою в більш тривалі терміни вегетаційного періоду.

3. При спільній роботі дрен мілко-глибокого закладання, на стік з мілкої дрени впливає глибока дрена і чим більший напір буде в гирлі глибокої дрени, тим менший стік спостерігається з мілкої дрени і навпаки.

4. На основі даних досліджень дренажно-модульних систем, можемо стверджувати, що дренажні модульні системи більш ефективні для регулювання водного режиму ґрунтів, і це вимагає подальших досліджень їх гідрологічної дії.

5. Отримані теоретично-експериментальним шляхом рівняння $(14 ; 21 ; 22)$ пропонується використовувати для розрахунку при проектуванні відстаней між досконалими дренами мілкого і мілко- 
глибокого закладання ДМС при ґрунтовому водному живленні.

1. Маслов Б. С., Станкевич В. С., Черненок В. Я. Осушительноувлажнительные системы. Москва : Колос, 1980. 279 с. 2. Мурашко А. И. Горизонтальный пластмассовый дренаж. Мн. : Ураджай, 1973. 208 с. 3. Кожушко Л. Ф. Вдосконалення інженерних рішень при реконструкції дренажних систем. Гідромеліорація та гідротехнічне будівництво : науковотехнічний збірник. Рівне, 1997. Вип. 21. С. 88-93. 4. Дренажно-модульна система: пат. № 49770 України. МПК ЕО2В 3/00. БВ № 17, 2010. 5. Аверьянов С. Ф. Борьба с засолением орошаемых земель. М. : Колос, 1978. 288 с. 6. Олейник А. Я. Геогидродинамика дренажа. Киев : Наукова думка, 1981. 283 с. 7. Лазарчук Н. А., Муранов В. Г., Черенков А. В. Оптимизация параметров дренажа в зоне осушения УССР. Мелиорация и водное хозяйство. 1989. № 7. С. 40-41. 8. Климков В. Т. Совершенствование конструкций мелиоративных систем на основе полимерных материалов : автореф. дисс. ... д-ра техн. наук. Минск, 1996. 33 с. 9. Рокочинський А. М. Оптимізація водорегулювання осушуваних земель. Водне господарство України. 1977. № 2. С. 4-5. 10. Ткачук М. М., Ткачук Р. М. Розрахунки параметрів дренажного модуля влаштованого з досконалих дрен, що працюють на інтенсивне пониження РГВ при надлишковому зволоженні. Вісник НУВГП : зб. наук. праць. Рівне, 2006. Вип. 1(33). С. 69-76.

\section{REFERENCES:}

1. Maslov B. S., Stankevich V. S., Chernenok V. Ya. Osushitelno-uvlazhnitelnye sistemy. Moskva : Kolos, 1980. 279 s. 2. Murashko A. I. Horizontalnyi plastmassovyi drenazh. Mn. : Uradzhai, 1973. 208 s. 3. Kozhushko L. F. Vdoskonalennia inzhenernykh rishen pry rekonstruktsii drenazhnykh system. Hidromelioratsiia ta hidrotekhnichne budivnytstvo : naukovo-tekhnichnyi zbirnyk. Rivne, 1997. Vyp. 21. S. 88-93. 4. Drenazhno-modulna systema: pat. № 49770 Ukrainy. MPK EO2V 3/00. BV № 17, 2010. 5. Averianov S. F. Borba s zasoleniem oroshaemykh zemel. M. : Kolos, 1978. 288 s. 6. Oleinyk A. Ya. Heohidrodinamika drenazha. Kyev : Naukova dumka, 1981. 283 s. 7. Lazarchuk N. A., Muranov V. H., Cherenkov A. V. Optimizatsyia parametrov drenazha v zone osusheniia USSR. Melioratsiia i vodnoe khoziaistvo. 1989. № 7. S. 40-41. 8. Klimkov V. T. Sovershenstvovanie konstruktsii meliorativnykh sistem na osnove polimernykh materialov : avtoref. diss. ... d-ra tekhn. nauk. Minsk, 1996. 33 s. 9. Rokochynskyi A. M. Optymizatsiia vodorehuliuvannia osushuvanykh zemel. Vodne hospodarstvo Ukrainy. 1977. № 2. S. 4-5. 10. Tkachuk M. M., Tkachuk R. M. Rozrakhunky parametriv drenazhnoho modulia vlashtovanoho $z$ doskonalykh dren, shcho pratsiuiut na intensyvne ponyzhennia RHV pry nadlyshkovomu zvolozhenni. Visnyk NUVHP : zb. nauk. prats. Rivne, 2006. Vyp. 1(33). S. 69-76. 
Tkachuk M. M., Doctor of Engineering, Professor, Tkachuk R. M., Candidate of Engineering (Ph.D.), Biletskyi A. A., Candidate of Engineering (Ph.D.), Associate Professor (National University of Water and Environmental Engineering, Rivne)

\section{WATER REGULATION OF DRAINAGE-MODULAR SYSTEMS ON DRYED LAND}

The article discusses water regulation by drainage-modular systems with different levels connecting control drains on drained lands, shows the diagrams of their design parameters. The research results and methods for calculating the parameters of these systems are presented. A new solution to the scientific and technical problem is substantiated, which consists in improving the design and improving the technology of water regulation of drained lands based on a combination of self-regulation and accumulation of water by installing a drainage-modular system with different levels of connection of hydraulically coupled control drains. Design and technical and technological parameters of such drainage-modular systems (regime of groundwater levels, depth of drainage, distance between them, drainage flow modules, moisture accumulation), their interaction and impact on the effectiveness of water regulation have been theoretically substantiated theoretically and investigated in laboratory and field conditions. The regularities of the formation of drainage flow and water regime of soils depending on the parameters of the drainage-modular system are investigated. It has been established that the necessary drainage intensity during the sowing period and during floods can be provided by a drainage-modular system with hydraulically connected regulating drains, while an important condition for designing a drainage-modular system is that hydraulically connected regulating drains that are arranged side by side must be laid on different the depths which ensures the best efficiency of their work under different modes of ground feeding, while deep drainage is more effective when connected to shallow and deep collectors at the same time. It has been established that, compared with traditional irrigation and drainage systems, drainagemodular systems during the growing season, with an increase in the difference between drains, accumulate groundwater within deep and shallow drains. The generally accepted methods and mathematical models have been improved that describe the movement of water in 
the ground for calculating the main parameters (laying depth, distance and difference between drains) of VHI with different level hydraulically connected regulating drains. The technology for the construction of VHI with hydraulically coupled different levels of regulating drains has been improved, which can significantly accelerate the pace of the construction of the regulatory network, reduce the complexity of work and the cost of construction. It is shown that this development in terms of technological and environmental efficiency occupies an intermediate place between traditional preventive and humidification locks and is the best in terms of economic efficiency and investment attractiveness.

Keywords: water regulation, improvement of water regulation, drainage-modular systems, multilevel regulating drains, drained lands.

Ткачук Н. Н., А.Т.н., профессор, Ткачук Р. М., к.т.н., Белецкий А. А., к.т.н., доцент (Национальный университет водного хозяйства и природопользования, м. Ровно)

ВОДОРЕГУЛИРОВАНИЕ ДРЕНАЖНО-МОДУЛЬНЫМИ СИСТЕМАМИ НА ОСУШАЕМЫХ ЗЕМЛЯХ

В статье рассмотрено водорегулирование дренажно-модульными системами с разноуровневым подключением регулирующих дрен на осушаемых землях, приведены схемы их конструктивных параметров. Приведены результаты исследований и методы расчета параметров этих систем.

Ключевые слова: водорегулирование, совершенствование водорегулирования, дренажно-модульные системы, разноуровневые регулирующие дрены, осушаемые земли. 